\title{
Performans Produktivitas Ayam KUB-2 Fase Produksi Telur pada Generasi ke-4
}

\section{(Performance Productivity of Laying Hen KUB-2 chicken at Fourth Generation)}

\author{
Sartika T, Iskandar S \\ Balai Penelitian Ternak, Ciawi-Bogor \\ tikesartika@hotmail.com
}

\begin{abstract}
KUB-2 is the chicken selected from KUB-1 chicken, which were selected to more egg production and yellow shank. KUB-1 chicken has 64\% various of black feather color, which sometime tends to have unprefered dark carcass. Yellow shank color has positive correlation with skin color of carcass. This research aims to produce KUB-2, which more egg production than KUB-1 and to know the yellow shank will be affected or no to the egg production. As many as 517 pullets of KUB-2 at $4^{\text {th }}$ generation were divided into two groups of 194 pullets of KUB-2kk (yellow shank) and 323 pullets of KUB-2nk (non yellow shank). The chickens were raised intensively in the individual cages for the 24 weeks observation. Variable measured was AFE, BWFE, EWFE, egg production during 24 weeks, mortality, AEW, feed consumption and FCR. The result indicated that there was no significant between KUB-kk and KUB-nk at 4th generation in evaluation for AFE, BWFE, EWFE and EP. AFE was 156.87 days, BWFE was 1795.4 g, EWFE was 31.26 g, EP during 24 weeks was 102.8 eggs or $61,2 \%$, mortality was low $0.98 \%$, the average of egg weight increases with increasing age of the chicken. FC $100 \mathrm{~g} / \mathrm{hen} /$ day, and FCR 3.54.
\end{abstract}

Key words: KUB-2 at $4^{\text {th }}$ generation, egg production, selection result

\begin{abstract}
ABSTRAK
Ayam KUB-2 adalah ayam hasil seleksi dari KUB-1 yang ditingkatkan lagi produksi telurnya dan diseleksi ke arah warna shank/kaki kuning. Ayam KUB-1, sebanyak 64\% mempunyai variasi warna hitam, kadangkala berpengaruh terhadap warna kulit karkas menjadi agak gelap. Warna shank kuning mempunyai korelasi positif dengan warna kulit karkas. Tujuan penelitian ini untuk menghasilkan bibit ayam KUB-2 dengan produksi telur lebih tinggi dari KUB-1 dan juga ingin mengetahui warna shank kuning berpengaruh tidak terhadap produksi telur. Sebanyak 517 ekor pullet ayam KUB-2 hasil seleksi generasi ke-4 yang terdiri atas 194 ekor KUB-kk (kaki kuning) dan 323 ekor KUB-nk (non kuning). Semua ayam ditempatkan pada kandang individu dan dievaluasi selama 24 minggu masa produksi telur. Peubah yang diamati adalah UPB, BIPB, BTP, rataan bobot telur, produksi telur selama 6 bulan (24 minggu), mortalitas, konsumsi, dan konversi pakan. Hasil penelitian menunjukkan bahwa UPB, BIPB, BTP, dan produksi telur ayam KUB-kk dan KUB-nk pada generasi ke-4 tidak berbeda nyata. Secara keseluruhan menghasilkan UPB sebesar 156,87 hari, BIPB sebesar 1795,4 g, BTP sebesar 31,26 g, produksi telur selama 24 minggu sebesar 102,8 butir atau 61,2\%. Mortalitas sangat rendah 0,98\%. Rataan bobot telur meningkat seiring meningkatkatnya umur ayam, konsumsi pakan 100 g/ekor/hr dan konversi pakan 3,54.
\end{abstract}

Kata kunci: KUB-2 generasi ke-4, produksi telur, hasil seleksi 


\section{PENDAHULUAN}

Dalam menunjang penyediaan bibit ayam lokal secara Nasional, Badan Litbang Pertanian khususnya Balitnak telah menghasilkan galur baru ayam KUB-1/Kampung Unggul Badan Litbangtan edisi ke-1, SK Mentan Nomor 274/Kpts/SR.120/2/2014 (Ditjen PKH 2014) dengan keunggulan utama adalah rataan produksi telur henday $50 \%$, atau menghasilkan telur sebanyak 160-180 butir/ekor/tahun. Penampilan warna bulu 64\% berwarna dasar variasi hitam, demikian juga warna shank (kaki) 74\% berwarna hitam (Sartika et al. 2013). Warna shank berkorelasi positif dengan warna kulit karkas maupun warna paruh (Gao et al. 2017).

Ayam lokal China Xianju dan Baler Yellow dengan warna shank kuning mempunyai warna kulit kuning, paruh kuning dan warna bulu penutup kuning merah buff serta diperuntukkan sebagai penghasil telur, sedangkan yang mempunyai warna shank hitam atau abu biasanya mempunyai warna kulit putih atau abu, warna paruh hitam abu, warna bulu utama hitam abu campur merah pada jantannya dan bintik spot pada betinanya seperti ayam lokal China Chongren Partridge dan ayam Dongxiang Blue yang diperuntukkan sebagai penghasil telur dan daging (Gao et al. 2017). Di Indonesia ayam lokal yang mempunyai warna shank kuning, kulit kuning warna bulu kuning merah buff pola kolumbian adalah ayam Merawang dan ayam Nunukan, kedua rumpun ayam lokal inipun berasal dari China (Sartika et al. 2016). Secara genetik warna shank kuning juga dipengaruhi oleh gen beta-carotene dioxygenase 2 (BCDO2) yang dijadikan marka genetik untuk menelusuri gen yang mempengaruhi warna shank (Ericksson et al. 2008; Gao et al. 2017). Dikatakan pula bahwa shank warna kuning adalah turunan atau satu klaster dengan grey junglefowl (Gallus sonneratii), sedangkan warna putih/abu/hitam adalah turunan atau satu klaster dengan red junglefowl (Gallus gallus).

Pada ayam KUB-1 walaupun produksi telurnya sudah baik, namun masih bisa ditingkatkan lagi karena variasi produksi telur pada ayam KUB-1 masih tinggi. Perbaikan genetik dengan cara seleksi walaupun lama namun dapat menghasilkan kualitas produksi yang permanen (Padhi 2016), sedangkan perbaikan genetik dengan crossbreeding sangat cepat meningkatkan produktivitas namun seringkali menguras sumberdaya genetik aslinya (Dessie et al. 2011). Beberapa negara berkembang di Afrika dan Asia telah melakukan peningkatan produktivitas ayam lokal baik melalui seleksi maupun crossbreeding seperti di Ethiopia (Mengesha 2012; Hailu et al. 2014; Gebremariam et al. 2017; Terfa et al. 2019), di Kenya (Magothe et al. 2015; Kamau et al. 2019), di Nigeria (Nwogwugwu et al. 2018), di Ghana (Amponsah et al. 2015), di India (Haunshi et al. 2019), di Thailand (Suphawadee \& Tuan 2016) dan Indonesia (Sartika et al. 2013; Iskandar \& Sartika 2014).

Ayam KUB-1 telah menjadi salah satu pasokan protein hewani secara nasional di Indonesia, karena telah dilisensi oleh swasta dan saat ini lisensor yang terbesar adalah PT Sumber Unggas Indonesia yang breeding farm-nya mempunyai indukan 120 ribu ekor, dapat menghasilkan DOC 600 ribu/bulan atau 7,2 juta/tahun. Tulisan ini mengemukakan bahwa ayam KUB-2 yang diseleksi lagi terhadap produksi telur dan warna shank kuning saat ini sudah mencapai generasi ke-4 yang mempunyai performans produksi telur lebih baik dibandingkan ayam KUB-1. Selain itu, ingin mengetahui apakah warna shank berpengaruh atau tidak terhadap performans produktivitas ayam KUB-2 fase produksi telur. 


\section{MATERI DAN METODE}

Sebanyak 517 ekor pullet ayam KUB-2 hasil seleksi generasi ke-4 umur 16 minggu, dibagi atas dua kelompok warna kaki/shank, yaitu 194 ekor berwarna kaki/shank kuning (KUB-kk) dan 323 ekor berwarna shank non kuning (KUB-nk). Kriteria seleksi adalah produksi telur $40 \%$ terbaik dan warna shank kuning. Ayam indukan ditempatkan pada kandang individu dengan ukuran panjang x lebar x tinggi: 35 x 40 x $40 \mathrm{~cm} 3$, pemberian pakan diberikan 100 g/ekor/hr. Komposisi pakan terdiri atas 75\% pakan jadi komersial layer (dengan protein 17\%, energi metabolis $2850 \mathrm{kkal} / \mathrm{kg}$, kalsium 3,4\%, dan serat kasar $5 \%$ ); $24 \%$ pollard dan $1 \%$ mineral premix. Nilai gizi pakan hasil perhitungan mengandung protein kasar 16,1\%, energi metabolis $2800 \mathrm{kkal} / \mathrm{kg}$, kalsium 3,2\%, Fosfor 0,5\%, asam amino lisin 0,9\%, asam amino methionin 0,45\%, dan serat kasar 6,15\% (Sinurat et al. 2014 dengan modifikasi penggantian dedak padi dengan pollard). Pemberian air minum tersedia sepanjang hari. Kadang kala diberikan pula feed suplemen egg stimulant pada air minumnya. Pemeliharaan ayam penelitian telah memenuhi persyaratan kesejahteraan hewan dari Komisi Kesejahteraan Hewan Badan Litbang Pertanian (KKHB)/Balitnak/A/01/2018.

Peubah yang diamati adalah: umur pertama bertelur (UPB), bobot induk pertama bertelur (BIPB), bobot telur pertama (BTP), rataan bobot telur (RBT), dan produksi telur harian selama 24 minggu (6 bulan), mortalitas selama pengamatan dan konversi pakan. Analisis statistik untuk mengetahui perbedaan produktivitas ayam KUB-kk vs KUB-nk, digunakan uji T-test dengan software Minitab version 14.

\section{HASIL DAN PEMBAHASAN}

\section{UPB, BIPB, BTP dan RBT}

Umur pertama bertelur (UPB) antara ayam KUB-kk dan KUB-nk generasi ke-4 secara statistik tidak berbeda nyata (Tabel 1). Rataan UPB secara keseluruhan sebesar 156,9 hari atau sekitar 22,4 minggu. Rataan UPB 22 minggu ini sangat ideal, berada pada kisaran normal UPB ayam KUB saat ini dan sudah lebih baik dari ayam KUB-1 pada populasi dasarnya yaitu sebesar 166,9-183,1 hari (Sartika et al. 2013). Faktor seleksi produksi telur berpengaruh terhadap UPB. Haunshi et al (2019) pada ayam lokal Aseel India yang diseleksi selama 8 generasi mendapatkan UPB sebesar 159,7 hari menurun dari populasi awalnya sebesar 173,9 hari. Demikian pula pada ayam lokal Horro Ethiopia hasil seleksi selama 7 generasi mendapatkan UPB sebesar 159,5 hari (Wondmeneh et al. 2016). Pada penelitian ini UPB tercepat diperoleh pada umur 112 hari atau sekitar 16 minggu namun tidak banyak dibawah 3\% dari populasi termasuk yang bertelur sekitar 1619 minggu masih sangat sedikit. Pada umur 20 minggu ayam sudah bertelur sekitar 10\%, produksi sekitar $10 \%$ inilah yang dijadikan patokan minggu pertama perhitungan produksi telur. UPB terlalu cepat juga tidak baik akan menyebabkan berat telurnya kecil dan akan cepat pula berhenti masa produksinya. Mengesha (2012) mendapatkan UPB pada ayam lokal Ethiopia sebesar 157-161 hari atau sekitar 5,35 bulan pada pemeliharaan intensif, sedangkan pada pemeliharaan semi intensif sekitar 6,25-6,42 bulan. Belay et al. (2018) juga mendapatkan UPB sekitar 6 bulan pada ayam Koekoek yang dipelihara dipedesaan. Assefa et al. (2018) mendapatkan pemeliharaan ayam lokal Ethiopia didataran sedang mempunyai UPB lebih lama tetapi produksi telurnya lebih tinggi dibandingkan yang dipelihara didataran rendah. Hasil penelitian ini juga menunjukkan UPB berkorelasi negatif dengan produksi telur $(\mathrm{P}<0,01)$, dengan nilai $\mathrm{R}=-0,57$. Artinya 
UPB lebih cepat akan menghasilkan produksi telur yang lebih rendah. Pada ayam lokal asli Ethiopia (indigenous), Sasso dan Koekoek yang dipelihara di dataran sedang mempunyai UPB sebesar 252, 162 dan 184 hr mendapatkan produksi telur sebesar 53,7, 137 dan 148 butir/ekor/tahun, sedangkan yang dipelihara didataran rendah mendapatkan UPBnya lebih cepat sebesar 224, 147 dan 148 hari namun mendapatkan produksi telur yang lebih rendah, yaitu sebesar 44,6, 129 dan 115 butir/ekor/tahun.

Tabel 1. Umur pertama bertelur (UPB), bobot induk pertama bertelur (BIPB) dan bobot telur pertama (BTP) ayam KUB-2 generasi ke-4

\begin{tabular}{|c|c|c|c|c|c|c|c|}
\hline \multirow{2}{*}{$\begin{array}{l}\text { Warna } \\
\text { shank }\end{array}$} & \multirow[b]{2}{*}{$\mathrm{N}$} & \multirow[b]{2}{*}{ Rataan (hr) } & \multicolumn{3}{|c|}{ Umur pertama bertelur (UPB) } & \multirow[b]{2}{*}{ Nilai-t } & \multirow[b]{2}{*}{ Nilai P } \\
\hline & & & Stdev (hr) & Min (hr) & $\begin{array}{l}\text { Maks } \\
\text { (hr) }\end{array}$ & & \\
\hline KUB-kk & 194 & 158,1 & 26,2 & 112 & 245 & 0,90 & 0,367 \\
\hline KUB-nk & 323 & 156,2 & 21,0 & 114 & 244 & & \\
\hline Total & 517 & 156,9 & 23,1 & 112 & 245 & & \\
\hline
\end{tabular}

Bobot induk pertama bertelur (BIPB)

\begin{tabular}{lcclllll} 
& & Rataan (g) & Stdev (g) & Min (g) & Maks (g) & Nilai-t & Nilai P \\
\hline KUB-kk & 194 & 1808 & 240 & 1220 & 2782 & 0,92 & 0,356 \\
KUB-nk & 323 & 1788 & 231 & 1178 & 2649 & & \\
Total & 517 & 1795 & 234 & 1178 & 2782 & & \\
\hline
\end{tabular}

Bobot telur pertama (BTP)

\begin{tabular}{lcclllll} 
& & Rataan (g) & Stdev (g) & Min (g) & Maks (g) & Nilai-t & Nilai P \\
\hline KUB-kk & 194 & 31,34 & 5,44 & 19 & 52 & 0,27 & 0,790 \\
KUB-nk & 323 & 31,32 & 4,67 & 17 & 51 & & \\
Total & 517 & 31,26 & 4,97 & 17 & 52 & & \\
\hline
\end{tabular}

Bobot induk pertama bertelur (BIPB) antara ayam KUB-kk maupun KUB-nk juga tidak berbeda nyata, secara keseluruhan BIPB sebesar $1795 \mathrm{~g}$ (Tabel 1). BIPB pada ayam KUB-2 generasi ke-4 ini sudah lebih tinggi dari KUB-1 yaitu sebesar 1,6 kg (Sartika et al. 2013; Iskandar \& Sartika 2014). BIPB sebesar 1,6-1,8 kg pada umur 22 minggu ini merupakan bobot yang ideal sebagai calon induk/bobot dewasa untuk memulai produksi telur. Milkias et al (2019) mendapatkan bobot induk ayam lokal asli Ethiopia umur 6 bulan pada berbagai agroekosistem hanya mempunyai rataan sebesar 1,48 kg, sehingga produksi telurnya pun lebih rendah dari penelitian ini. Haunshi et al (2019) pada ayam

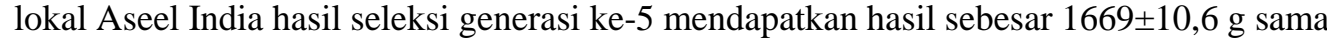
baiknya dengan hasil penelitian ini.

Bobot telur pertama (BTP) antara ayam KUB-kk dengan KUB-nk secara statistik tidak berbeda nyata (Tabel 1), Secara keseluruhan BTP diperoleh sebesar 31,26 g. Rataan BTP sebesar $31 \mathrm{~g}$ untuk breed ayam lokal (indigenous chicken) sudah cukup baik, walaupun masih ada yang berat minimumnya 19 gram. Rataan bobot telur (RBT) dari umur 18-20 minggu sekitar 30 gram. Semakin bertambah umur ayam, bobot telur akan semakin meningkat (Amponsah et al. 2015), hal yang sama juga diperoleh dari penelitian ini seperti disajikan pada Tabel 2. Hasil pengamatan sampai dengan umur 24 minggu RBT ayam baru mencapai 35,7 gram, sehingga belum bisa ditetaskan. Bobot telur tetas berkorelasi positif dengan bobot DOC, semakin besar bobot telur tetas semakin besar 
pula bobot DOC nya. Bobot DOC untuk ayam KUB saleable chick (yang dapat dijual) SNI nya sebesar 26 gram atau diperoleh dari berat telur tetas minimal 38 gram. Pada penelitian ini menunjukkan pada ayam umur 25 minggu mempunyai rataan RBT sebesar 39 gram sudah baik utk ditetaskan.

Tabel 2. Rataan bobot telur (RBT) ayam KUB-2 generasi ke-4

\begin{tabular}{llcc}
\hline Umur ayam & & $\begin{array}{c}\text { Ayam KUB-kk } \\
\text { Minggu ke- }\end{array}$ & $\begin{array}{c}\text { Ayam KUB-nk } \\
(\mathrm{n}=390)\end{array}$ \\
\hline $18-20$ & Rataan (g) & $30,01 \pm 2,41$ & $29,99 \pm 2,10$ \\
& CV (\%) & 8,04 & 7,03 \\
$21-24$ & Rataan (g) & $35,70 \pm 1,56$ & $35,71 \pm 1,88$ \\
$25-28$ & CV (\%) & 4,36 & 5,27 \\
& Rataan (g) & $39,10 \pm 1,05$ & $39,16 \pm 1,06$ \\
$29-32$ & CV (\%) & 2,57 & 2,70 \\
$33-36$ & Rataan (g) & $41,68 \pm 1,04$ & $41,60 \pm 0,73$ \\
& CV (\%) & 2,49 & 1,75 \\
$37-40$ & Rataan (g) & $43,50 \pm 0,88$ & $43,69 \pm 0,56$ \\
& CV (\%) & 2,04 & 1,28 \\
$41-44$ & Rataan (g) & $44,51 \pm 0,30$ & $44,79 \pm 0,75$ \\
& CV (\%) & 0,66 & 1,68 \\
& Rataan (g) & $45,65 \pm 0,48$ & $46,09 \pm 0,42$ \\
& CV (\%) & 1,04 & 0,92 \\
\hline
\end{tabular}

Pada ayam KUB-kk maupun KUB-nk, pada umur yang sama mempunyai RBT relatif sama. Pada ayam umur 40 minggu mempunyai RBT sebesar 44,5-44,8 g dan pada umur 44 minggu mempunyai berat sekitar 46 gram (Tabel 2). Besarnya bobot telur dipengaruhi pula oleh breed ayam tersebut, juga kualitas, dan jumlah pakan yang diberikan. Haunshi et al. (2019) pada ayam lokal Aseel India mendapatkan rataan bobot telur yang lebih besar, yaitu pada umur 40 minggu mencapai 48,9 g pada generasi ke-8 meningkat sebesar 1,3 g dari generasi pertamanya, sedangkan bobot telur $46 \mathrm{~g}$ diperoleh pada umur 32 minggu. Mengesha (2012) mendapatkan rataan bobot telur pada ayam lokal Ethiopia (indigenous chicken) sebesar 42-48 gram, dan pada ayam lokal Ghana umur 2248 minggu mendapatkan rataan 38-40,1 g (Amponsah et al. 2015), Namun pada ayam Koekoek Ethiopia mempunyai rataan berat telur cukup tinggi yaitu sebesar 52,5 g (Belay et al. 2018).

\section{Produksi telur}

Rataan produksi telur selama 6 bulan (24 minggu) ayam KUB-kk maupun KUB-nk pada generasi G-4 tidak berbeda nyata (Tabel 3). Secara keseluruhan rataan produksi telur pada umur 20-43 minggu selama 24 minggu mendapatkan 102,8 butir atau sebesar 61,2 $\pm 15,8 \%$. Hasil ini lebih baik dibandingkan dengan KUB-1 (Sartika et al. 2013; Iskandar \& Sartika 2014), keragaman produksi telur hasil seleksi ayam KUB-2 generasi ke-4 ini juga lebih rendah dibandingkan KUB-1, yaitu sebesar 25,87\%. Produksi telur tertinggi dapat dicapai oleh individu ayam sebesar 154 butir dalam 168 hari (24 minggu) 
atau sebesar 91,67\%. Produksi telur terendah hanya 5 butir/168 hari atau hanya sebesar 2,98\% (Tabel 3). Haunshi et al. (2019) pada ayam lokal Aseel India hasil seleksi selama 8 generasi mendapatkan produksi telur sampai dengan 40 minggu sebesar 78,6 butir atau $53,47 \%$, naik dari populasi awalnya yang hanya sebesar 59,5 butir atau 40,48\%. Milkias et al. (2019) pada ayam lokal Ethiopia di Distrik Gena Bossa pada berbagai agroekosistem dataran rendah, sedang dan tinggi dengan pemeliharaan tradisional mendapatkan hasil produksi telur yang sangat rendah dibandingkan dengan penelitian ini yaitu 38,73; 40,45; 36,42 butir/ekor/tahun. Untuk meningkatkan produksi telur di Ethiopia, pemerintahnya mendatangkan breed exotic, untuk disilangkan dengan ayam lokal di Ethiopia (Terfa et al. 2019). Hal tersebut telah dilakukan Wondmeneh et al (2016) yang melakukan evaluasi produksi telur improve breed ayam Horro, komersial breed ayam ISA Brown, crossbred (ISA Brown X Horro) dan ayam lokal asli Ethiopia mendapatkan produksi telur hen house selama 6 bulan untuk masing-masing breed tersebut sebesar 57,1\%; 92,2\%; 83\% dan 27,1\%. Ayam Horro merupakan breed ayam lokal yang ditingkatkan produksinya, hasil seleksi selama 7 generasi setara dengan ayam KUB.

Tabel 3. Performans produksi telur ayam KUB-2 generasi ke-4 selama 24 minggu

\begin{tabular}{|c|c|c|c|c|c|c|c|}
\hline \multirow{2}{*}{$\begin{array}{l}\text { Warna } \\
\text { shank }\end{array}$} & \multirow[b]{2}{*}{$\mathrm{N}$} & \multirow{2}{*}{$\begin{array}{c}\text { Rataan } \\
\text { (btr) }\end{array}$} & \multicolumn{5}{|c|}{ Produksi telur umur 20-43 minggu (168 hari) } \\
\hline & & & Stdev (btr) & $\begin{array}{l}\text { Min } \\
\text { (btr) }\end{array}$ & $\begin{array}{c}\text { Maks } \\
\text { (btr) }\end{array}$ & Nilai-t & Nilai P \\
\hline KUB-kk & 190 & 101,9 & 27,8 & 5 & 154 & \multirow{3}{*}{$-0,57$} & \multirow{3}{*}{0,570} \\
\hline KUB-nk & 322 & 103,3 & 25,9 & 5 & 151 & & \\
\hline \multirow[t]{2}{*}{ Total } & 512 & 102,8 & 26,6 & 5 & 154 & & \\
\hline & & Rataan (\%) & Stdev (\%) & $\operatorname{Min}(\%)$ & Maks (\%) & Nilai-t & Nilai $\mathrm{P}$ \\
\hline KUB-kk & 190 & 60,7 & 16,5 & 2,98 & 91,67 & \multirow{3}{*}{$-0,57$} & \multirow{3}{*}{0,570} \\
\hline KUB-nk & 322 & 61,5 & 15,4 & 2,98 & 89,88 & & \\
\hline Total & 512 & 61,2 & 15,8 & 2,98 & 91,67 & & \\
\hline
\end{tabular}

Pada ayam KUB-2 generasi ke-4 mempunyai puncak produksi telur hen day sebesar 75,4\% pada umur 35 minggu. Produksi telur hen day mencapai diatas 60\% diperoleh pada ayam umur 24 minggu dan dapat bertahan sampai minggu ke-41 masih tetap mempunyai rataan hen day diatas $60 \%$, bahkan pada ayam KUB-nk sampai pengamatan umur 43 minggu masih tetap berada diatas 60\%. Grafik produksi telur hen day setiap minggu untuk ayam KUB-2 kk dan nk generasi ke-4 disajikan pada Gambar 1. Produksi telur pada ayam KUB-2 ini jauh lebih baik dibandingkan dengan KUB-1 (Sartika et al. 2013), juga Amponsah et al. (2015) pada ayam lokal Ghana Savanah dan Forest menghasilkan produksi telur yang rendah, namun ayam exotic Sasso dari Perancis mempunyai puncak produksi 90\% pada minggu ke-6-8 setelah produksi. Produksi telur selain dipengaruhi oleh breed ayam juga sangat tergantung pada pakan yang diberikan baik kualitas maupun kuantitas, air yang diminum, intensitas dan lama cahaya, manajemen pemeliharaan, termasuk biosekuriti adanya penyakit dan parasit serta pengaruh lingkungan lainnya (Amponsah et al. 2015). 


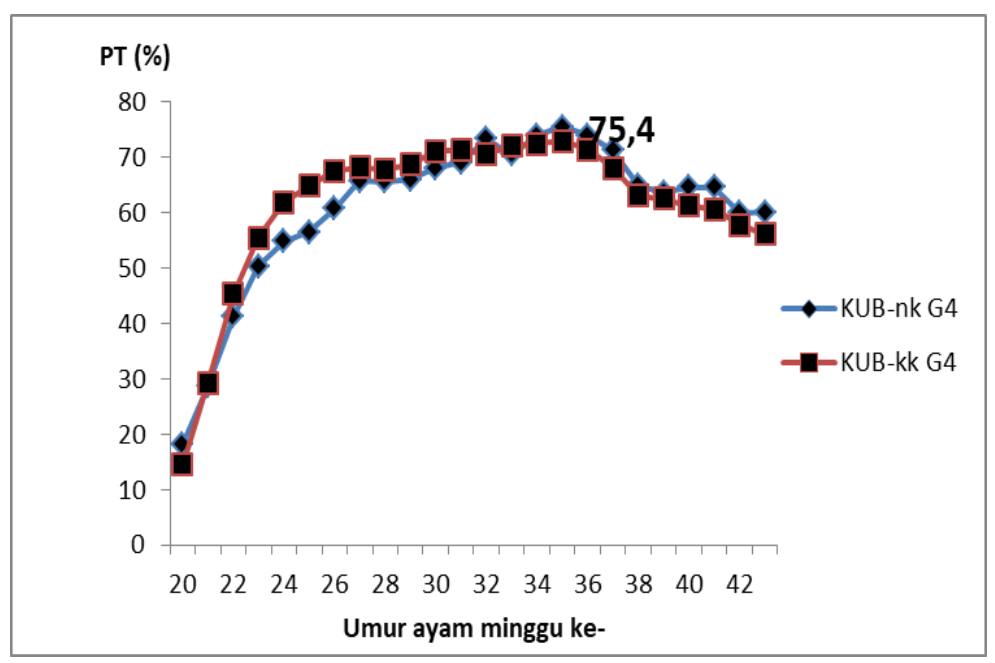

Gambar 1. Grafik produksi telur hen day ayam KUB-2 generasi ke-4

Berdasarkan kemampuan individu ayam KUB-2 generasi ke-4 ini, ada ayam yang menghasilkan produksi telur sangat tinggi, yaitu sebesar $>80 \%$, namun jumlahnya tidak banyak hanya 7,2\% dari jumlah ayam pengamatan 512 ekor indukan (Gambar 2).

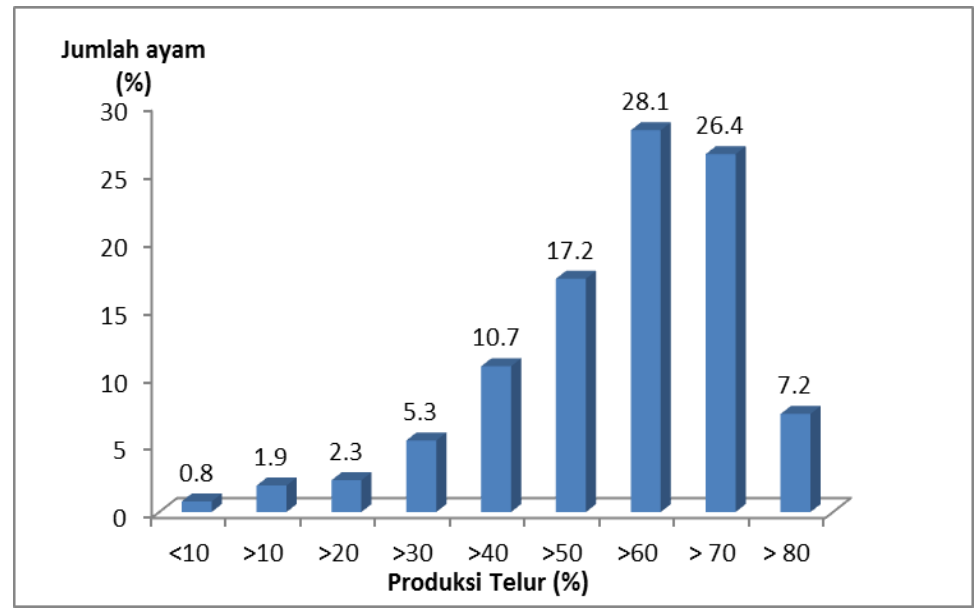

Gambar 2. Grafik kemampuan produksi individu ayam KUB-2 generasi ke-4

Dengan kata lain ada sebanyak 37 ekor ayam yang mempunyai rataan produksi telur $>140,2$ butir dalam pengamatan 24 minggu atau 168 hari. Ayam yang terbanyak adalah yang dapat menghasilkan produksi telur $>60 \%$ atau mempunyai rataan produksi telur sebesar 109,8 butir dan $>70 \%$ atau mempunyai rataan produksi telur sebesar 124,1 butir. Ayam yang memiliki produksi telur rendah $<50 \%$ hanya berjumlah $21 \%$. Artinya sebanyak 79\% dari populasi ayam KUB-2 hasil seleksi generasi ke-4 mempunyai produksi telur cukup tinggi yaitu $>50 \%$, secara kumulatif mempunyai rataan sebesar 113,8 butir. Variasi individu ayam untuk menghasilkan telur selama pengamatan masih sekitar 25,87\%, dengan kata lain seleksi masih bisa diteruskan untuk lebih meningkatkan produksi dan kestabilan produksi telur. Padhi (2016) menyatakan seleksi pada ayam lokal 
asli/ indigenous chicken akan meningkatkan produktivitas yang permanen, walaupun memerlukan waktu yang cukup lama. Pada ayam Koekoek di Ethiopia telah mempunyai produksi telur sebesar 180-240 butir/ekor/tahun (Belay et al. 2018) dan pada ayam KUB1 baru mencapai 160-180 butir/ekor/tahun (Sartika et al. 2013). Pada penelitian ini ayam KUB-2 generasi ke-4 telah mencapai produksi telur sebanyak 102 butir/ekor/6 bulan diperlukan pengamatan selama 1 tahun produksi, dengan target minimal 180-220 butir/ekor/tahun.

\section{Konsumsi, FCR dan mortalitas ayam selama pengamatan}

Feed conversion ratio (FCR) dihitung berdasarkan berapa jumlah pakan yang dikonsumsi (gram) dibagi dengan jumlah telur yang dihasilkan kali berat telur (gram). Konsumsi pakan ditetapkan sebanyak 100 g/ekor/hari, tidak dihitung secara akurat karena banyak faktor yang masih perlu perbaikan manajemen, adanya tikus, burung, pakan tumpah dan lainnya ikut berpengaruh terhadap konsumsi pakan (Tabel 4). Pada ayam KUB-1 konsumsi pakan sekitar 80-85 gram (Sartika et al. 2013), dengan rataan produksi telur 50\%. Pada penelitian ini produksi telur lebih besar yaitu sekitar 60\%, pemberian pakan ditetapkan sebanyak $100 \mathrm{~g} / \mathrm{ekor} / \mathrm{hr}$.

Tabel 4. Rataan FCR ayam KUB-2 generasi ke-4

\begin{tabular}{|c|c|c|c|}
\hline $\begin{array}{l}\text { Umur ayam } \\
\text { Minggu ke- }\end{array}$ & & $\begin{array}{l}\text { Ayam KUB-kk } \\
(\mathrm{n}=190)\end{array}$ & $\begin{array}{l}\text { Ayam KUB-nk } \\
(\mathrm{n}=322)\end{array}$ \\
\hline \multirow[t]{2}{*}{$20-24$} & Rataan & $9,01 \pm 5,18$ & $9,39 \pm 6,99$ \\
\hline & CV (\%) & 57,56 & 74,53 \\
\hline \multirow[t]{2}{*}{$25-28$} & Rataan & $4,14 \pm 0,41$ & $3,81 \pm 0,17$ \\
\hline & CV (\%) & 9,77 & 4,49 \\
\hline \multirow[t]{2}{*}{$29-32$} & Rataan & $3,48 \pm 0,24$ & $3,41 \pm 0,09$ \\
\hline & CV (\%) & 6,77 & 2,82 \\
\hline \multirow[t]{2}{*}{$33-36$} & Rataan & $3,13 \pm 0,14$ & $3,17 \pm 0,05$ \\
\hline & CV (\%) & 4,44 & 1,43 \\
\hline \multirow[t]{2}{*}{$37-40$} & Rataan & $3,41 \pm 0,18$ & $3,51 \pm 0,19$ \\
\hline & CV (\%) & 5,30 & 5,49 \\
\hline \multirow[t]{2}{*}{$41-43$} & Rataan & $3,57 \pm 0,14$ & $3,74 \pm 0,12$ \\
\hline & CV (\%) & 3,91 & 3,23 \\
\hline \multirow[t]{2}{*}{$25-43$} & Rataan FCR Produktif & $3,54 \pm 0,37$ & $3,53 \pm 0,26$ \\
\hline & CV (\%) & 10,43 & 7,34 \\
\hline
\end{tabular}

Pada umur ayam 20-24 minggu terlihat FCR cukup tinggi, yaitu sekitar 9-9,4 hal ini disebabkan pada umur 20 minggu produksi telur baru sekitar 10\% meningkat perlahan pada umur 24 minggu sekitar 40\% (Gambar 1) dan besarnya telur juga masih sekitar 3035 g, sehingga sampai umur 24 minggu belum bisa dijadikan telur tetas. Setelah ayam berumur 25 minggu baru dihitung FCR nya dalam hal ini produksi telur sudah meningkat stabil dan telur sudah dapat ditetaskan. Rataan FCR umur ayam 25-43 minggu sekitar 3,5 lebih baik dari hasil KUB-1 sebesar 3,8 (Sartika et al. 2013). Wondmeneh et al. (2016) memperoleh hasil FCR pada ayam Horro (improvement breed), komersial ISA brown, 
crossbred ISAxHorro dan ayam lokal asli ethiopia pada pengamatan 6 bulan produksi telur masing-masing sebesar 3,4; 2,4; 3,3 dan 7,1. Mortalitas selama pengamatan cukup rendah hanya ada kematian 5 ekor dari total ayam 517 ekor atau kematian hanya sekitar $0,98 \%$.

\section{KESIMPULAN}

Performans produktivitas Ayam KUB-2 generasi ke-4 sudah lebih baik dari KUB-1. Berdasarkan warna shank/kaki kuning dan shank non kuning tidak berbeda nyata terhadap UPB, BIPB, BTP dan produksi telur selama 6 bulan/ 24 minggu. Rataan UPB, BIPB dan BTP masing-masing sebesar 156,9 hari, 1795,4 g dan 31,26 g. Produksi telur selama 6 bulan sebesar 102,8 butir atau 61,2\%. Bobot telur meningkat dengan bertambahnya umur ternak. Pada umur 25 minggu bobot telur telah mencapai rataan $39 \mathrm{~g}$ dan telah siap untuk mulai ditetaskan. Mortalitas induk selama pengamatan sangat rendah yaitu sebesar 0,98\%. Konsumsi pakan diberikan 100 g/ekor/hari dan konversi pakan masa bertelur produkstif umur 25-43 minggu sebesar 3,54.

\section{UCAPAN TERIMA KASIH}

Penulis mengucapkan terima kasih atas bantuan dari semua pihak terutama tenaga teknisi, honorer dan UHL di kandang yang telah banyak membantu dalam kelancaran penelitian ini, staf administrasi yang mendukung ketersediaan bahan pendukung dalam penelitian ini, tenaga keswan yang melakukan SOP vaksinasi selama penelitian dan khususnya kepada bapak Kepala Balai Penelitian Ternak yang telah menyetujui pengalokasian dana APBN 2018, DIPA Balitnak, Badan Litbang Pertanian.

\section{DAFTAR PUSTAKA}

Amponsah O, Kayang BB, Naazie A, Tiexier-Boichard M, Rognon X. 2015. Phenotypic characterization of local Ghanaian chickens: Egg-laying performance under improved management conditions. Anim Genet Resources. 56:29-35.

Assefa S, Melesse A, Banerjee S. 2018. Egg production and linear body measurement traits of local and three exotic chicken genotypes reared under two agroecological zones. Int J Ecol Ecosolution. 5:18-23.

Belay S, Resom M, Yemane H, Amare H. 2018. Production performance evaluation of koekoek chicken under farmer management practice in Tigray region, northern Ethiopia. Int J Livest Prod. 9:232-237.

Dessie T, Taye T, Dana N, Ayalew W, Hanotte O. 2011. Current state of knowledge on phenotypic characteristics of indigenous chickens in the tropics. Small-Scale Family Poultry Production. World's Poult Sci J. 67.

[Ditjen PKH] Direktorat Jenderal Peternakan dan Kesehatan Hewan. 2014. SK Pelepasan Galur ayam KUB-1. KepMentan no274/Kpts/SR.120/2/2014. Jakarta (Indonesia): Direktorat Jenderal Peternakan dan Kesehatan Hewan, Kementerian Pertanian.

Eriksson J, Larson G, Gunnarsson U, Bed'hom B, Tixier-Boichard M, Stro“ mstedt L, Wright D, Jungerius A, Vereijken A, Randi E, Jensen P, Andersson L. 2008. Identification of the yellow skin gene reveals a hybrid origin of the domestic chicken. PLoS Genet. 4:e1000010. doi: 10.1371/journal.pgen.1000010. 
Gao Y, Jia X, Tang X, Fan Y, Lu J, Huang S, Tang M. 2017. The genetic diversity of chicken breeds from Jiangxi, assessed with BCDO2 and the complete mitochondrial DNA Dloop region. PLoS ONE. doi: 10.1371/journal.pone.0173192.

Gebremariam B, Mazengia H, Gebremariam T. 2017. Indigenous chicken production system and breeding practice in Southern Tigray, North Ethiopia. Poult Fisheries Wildlife Sci. 5:1. doi: 10.4172/2375-446X.1000179.

Hailu A, Wuletaw Z, Mazengia H. 2014. Breeding practice and objective of indigenous chicken in North Wollo, Amhara regional State, Ethiopia. Int J Livest Prod. 5:15-22. doi: 10.5897/IJLP12.0002.

Haunshi S, Rajkumar U, Padhi MK. 2019. Improvement of PD-4 (Aseel), an indigenous chicken, for growth and production traits. Indian J Anim Sci. 89:419-423.

Iskandar S, Sartika T. 2014. KUB chicken: The first Indonesian kampung chicken selected for egg production. Proceedings of the 16th AAAP Animal Science Congress Vol II. Yogyakarta (Indonesia): Gadjah Mada University. p. 157-160.

Kamau CN, Kabuage LW, Bett EK. 2019. Analysis of improved indigenous chicken adoption among small holder farmers: Case of Makueni and Kakamega counties, Kenya. Int J Agr Ext. 07:21-37. doi: 10.33687/ijae.007.01.2809.

Magothe TM, Okeno TO, Kahi TO. 2015. Genetic improvement of indigenous chicken in Kenya: The past, current and future efforts. APSK 2015 Proceedings. p. 147-158.

Mengesha M. 2012. Indigenous chicken production and the innate characteristic. Asian J Poult Sci. 6:56-64.

Milkias M, Molla M, Tilahun S. 2019. Productive and reproductive performance of indigenous chickens in Gena Bossa District of Dawro Zone, Ethiopia. Int J Livest Prod. 10:24-32.

Nwogwugwu CP, Lee JH, Freedom EC, Lee SH. 2018. Review on the genetic potential of Nigerian local chickens. J Anim Breed Genom. 2:2586-4297.

Padhi MK. 2016. Importance of Indigenous Breeds of Chicken for Rural Economy and Their Improvements for Higher Production Performance. Hindawi Publishing Corporation; Scientifica [Internet]. Article ID 2604685. Available from: http://dx.doi.org/10.1155/2016/2604685.

Sartika T, Iskandar S, Tiesnamurti B. 2016. Sumberdaya genetik ayam lokal Indonesia dan prospek pengembangannya. Jakarta (Indonesia): Badan Penelitian dan Pengembangan Pertanian, IAARD Press. $177 \mathrm{hlm}$.

Sartika T, Desmayati, Iskandar S, Resnawati H, Setioko AR, Sumanto, Sinurat AP, Isbandi, Tiesnamurti B, Romjali E. 2013. Ayam KUB-1. Jakarta (Indonesia): Badan Penelitian dan Pengembangan Pertanian, IAARD Press. 89 hlm.

Sinurat AP, Iskandar S, Resnawati H, Purba M, Desmayati Z. 2014. Pemberian pakan ayam KUB berbasis pakan lokal. Jakarta (Indonesia): Badan Penelitian dan Pengembangan Pertanian, IAARD Press. $95 \mathrm{hlm}$.

Suphawadee Y, Tuan NN. 2016. Phenotypic Characterization of native chicken ecotypes in lower northern, Thailand. The 17th Asian-Australasian Association of Animal Production Societies Animal Science Congress. p. 1131-1135.

Terfa ZG, Garikipati S, Kassie GT, Dessie T, Christley RM. 2019. Understanding farmers' preference for traits of chickens in rural Ethiopia. The Journal of the International Association of Agricultural Economics. Agric Economics. p. 1-13. doi: 10.1111/agec.12502. wileyonlinelibrary.com/journal/agec. 
Wondmeneh E, Vander Waaij EH, Udo HMJ, Tadelle D, Van Arendonk JAM. 2016. Comparison of different poultry breeds under station and on-farm conditions in Ethiopia. Livest Sci. 183:72-77. 